\title{
Dammarane-type triterpene ginsenoside-Rg18 inhibits human non-small cell lung cancer A549 cell proliferation via $G_{1}$ phase arrest
}

\author{
DONG-GYU LEEM ${ }^{1,2}$, JI-SUN SHIN $^{1}$, KYUNG-TACK KIM $^{3}$, SANG YOON CHOI ${ }^{3}$, \\ MYUNG-HEE LEE ${ }^{3}$ and KYUNG-TAE LEE ${ }^{1,2}$
}

\begin{abstract}
Departments of ${ }^{1}$ Pharmaceutical Biochemistry and ${ }^{2}$ Life and Nanopharmaceutical Science, College of Pharmacy, Kyung Hee University, Seoul 02447; ${ }^{3}$ Traditional Food Research Center, Korea Food Research Institute, Seongnam 13539, Republic of Korea
\end{abstract}

Received October 10, 2016; Accepted January 17, 2018

DOI: $10.3892 / \mathrm{ol} .2018 .8057$

\begin{abstract}
A previous study reported that a novel dammarane-type triterpene saponin, ginsenoside- $\mathrm{Rg} 18$, derived from the root of Panax ginseng, displayed hydroxyl radical scavenging, anti-bacterial and cytotoxic activities. However, the underlying molecular mechanisms of its anti-proliferative effect on non-small cell lung cancer (NSCLC) A549 cells remains unclear. In the present study, it was determined that $\operatorname{Rg} 18$ inhibited the proliferation of A549 cells with a half-maximal inhibitory concentration of $150 \mu \mathrm{M}$. Flow cytometry analysis indicated that cell cycle progression was blocked by $\mathrm{Rg} 18$ at $\mathrm{G}_{1}$ phase in A549 cells, which was accompanied by downregulation of cyclin-dependent kinase 2 (CDK2), CDK4, CDK6, cyclin D1, cyclin D2, cyclin $\mathrm{E}$ and phosphorylated retinoblastoma protein expression at the protein level. In addition, the CDK inhibitors (CDKNs), CDKN1A and CDKN1B, were upregulated following Rg18 treatment. Furthermore, Rg18 treatment resulted in the intracellular accumulation of reactive oxygen species (ROS), and a dose-dependent inhibition of $\mathrm{p} 38$ mitogen activated protein kinase (p38), c-Jun N-terminal kinase (JNK) and nuclear factor- $\kappa \mathrm{B}(\mathrm{NF}-\mathrm{\kappa B}) / \mathrm{p} 65$ phosphorylation. Taken together, $\operatorname{Rg} 18$-mediated $\mathrm{G}_{1}$ phase arrest was closely associated with the generation of intracellular ROS, and p38, JNK and NF- $\mathrm{kB} / \mathrm{p} 65$ inhibition in A549 human NSCLC cells.
\end{abstract}

Correspondence to: Dr Kyung-Tae Lee, Department of Pharmaceutical Biochemistry, College of Pharmacy, Kyung Hee University, Dongdaemun-Ku, Kyungheedae-ro 26, Seoul 02447, Republic of Korea

E-mail:ktlee@khu.ac.kr

Key words: ginsenoside, $\mathrm{G}_{1}$ phase arrest, reactive oxygen species, mitogen-activated protein kinase, nuclear factor- $\kappa \mathrm{B}$

\section{Introduction}

Lung cancer is one of the leading causes of cancer-associated mortality worldwide (1). Non-small-cell lung cancer (NSCLC) accounts for $\sim 80 \%$ all cases of lung cancer and has a 5-year survival rate of $15 \%$ (2). Resistance can be developed to contemporary chemotherapy regimens for NSCLC and various adverse side effects can be invoked (3). Therefore, the identification and development of more effective, less toxic antitumor NSCLC therapies is urgently required.

The cell cycle is a highly regulated mechanism of controlling cell growth, proliferation and survival. Cancer cells exhibit dysregulated cell cycles, with the overexpression of positive regulators and inhibition of negative regulators, resulting in unlimited replication potential (4). Therefore, the development of agents targeting the dysregulated cell cycle has been considered to be a suitable strategy for cancer therapy (3). Cell cycle progression depends on cyclin-dependent kinase (CDK) activation status, which act consecutively in $G_{1}$ phase to initiate $S$ phase and, in $G_{2}$ phase, to initiate mitosis. With mitogenic stimulation, cyclin D is activated, in turn activating CDK4 and 6. Cyclin D-dependent kinases phosphorylate retinoblastoma proteins $(\mathrm{Rb})$, which relieves transcription factor E2F1 from inhibition and allows for the expression of specific E2F1-target genes (5). The cyclin E-CDK2 complex concludes Rb phosphorylation and permits the activation of E2F1-responsive genes (6). Cyclin-CDK complexes are inhibited by two CDK inhibitor (CDKN) families: Inhibitors of CDKN4 (INK4) (p15 $5^{\mathrm{INK} 4 \mathrm{~B}}$, $\mathrm{p} 16^{\mathrm{INK} 4 \mathrm{~A}}, \mathrm{p} 18^{\mathrm{INK} 4 \mathrm{C}}$ and $\left.\mathrm{p} 19^{\mathrm{INK} 4 \mathrm{D}}\right)$ and CDKN1A (p21 $\left.1^{\mathrm{CIP} / / \mathrm{WAF} 1}\right)$, $1 \mathrm{~B}\left(\mathrm{p} 27^{\mathrm{KIP1}}\right)$ and $1 \mathrm{C}\left(\mathrm{p} 57^{\mathrm{KIP} 2}\right)$ (7). The CDKNs also perform central cell cycle-regulating functions, coordinating internal and external signals that modulate cell cycle progression (7). Thus, the cell cycle is tightly controlled in response to external and internal factors. In abnormal conditions, including DNA damage, cell cycle progression is inhibited to prevent harmful progression.

Reactive oxygen species (ROS) are chemically reactive molecules, including the superoxide anion, hydrogen peroxide and the hydroxyl radical. ROS are endogenously 
produced during metabolic activities of the cell, including the oxidative phosphorylation of mitochondria (8). ROS may also arise from reactions with exogenous sources, including xenobiotic compounds (9). Cellular function requires moderate ROS levels for normal cell signaling. However, ROS overproduction can be toxic to cells owing to their peroxidative activity (10). One proposed anticancer strategy is the use of exogenous ROS-stressing agents or inhibition of endogenous antioxidants to elevate intracellular ROS levels to toxic amounts, triggering cell cycle arrest in the target cancer cell (11).

Ginsenosides are triterpene saponins and the major pharmacologically active components extracted from the roots and rhizomes of various Panax species. Ginsenosides are responsible for the majority of functions of ginseng, including angiogenesis, vasorelaxation and antioxidation (8). These molecules also possess anti-inflammatory and anticancer properties (12-14). In a previous study, four dammarane-type triterpene saponins isolated from the Panax ginseng root exhibited effective hydroxyl radical scavenging ability, as well as antibacterial and cytotoxic activities (15). However, to the best of our knowledge, there has been no research into the anti-proliferative effects of these compounds or their underlying molecular mechanisms. As part of an ongoing screening program for the evaluation of the anti-proliferative potential of natural compounds, the mechanisms underlying the cell cycle-arresting activities of Rg18 in NSCLC A549 cells were investigated in the present study.

\section{Materials and methods}

Chemicals and reagents. Rg18 and Rs11 (Fig. 1A) were kindly provided by Dr. Kyung-Tack Kim (Korea Food Research Institute, Wanju-gun, South Korea), and its purity of $>96 \%$ was determined by high-performance liquid chromatography-mass spectrometry analyses (15). RPMI-1640 medium, fetal bovine serum (FBS), penicillin and streptomycin were all obtained from Thermo Fisher Scientific, Inc. (Waltham, MA, USA). MTT, phenylmethylsulfonyl fluoride (PMSF), $N$-acetylcysteine (NAC), 2',7'-dichlorofluorescin diacetate (DCFH-DA), bisacrylamide and sodium dodecyl sulfate were purchased from Sigma-Aldrich; Merck KGaA (Darmstadt, Germany). CDK2 (sc-163), CDK4 (sc-260), CDK6 (sc-7961), cyclin D1 (sc-8396), cyclin D2 (sc-593), cyclin E (sc-198), p21 CIP1/WAF1 (sc-397), p27 ${ }^{\mathrm{KIP1}}$ (sc-1641), Rb (sc-102), p38 mitogen activated protein kinase (p38, sc-535), c-Jun N-terminal kinase (JNK, sc-7345), extracellular signal-regulated kinase (ERK, sc-94), p65 (sc-372), p-JNK (sc-12882), p-ERK (sc-7383) and $\beta$-actin (sc-81178) primary antibodies were purchased from Santa Cruz Biotechnology, Inc. (Dallas, TX, USA). Phosphorylated (p)-Rb (no. 9307), p-p38 (no. 9215), p-p65 (Ser536, no. 3031) primary antibodies were purchased from Cell Signaling Technology, Inc. (Danvers, MA, USA). Proteinase K, ribonuclease A, and TEMED were purchased from Bio-Rad Laboratories, Inc. (Hercules, CA, USA).

Cell culture. The human lung adenocarcinoma A549 cell line was obtained from the Korean Cell Line Bank (Seoul, Korea). A549 cells were grown at $37^{\circ} \mathrm{C}$ in RPMI-1640, supplemented with $10 \%$ fetal bovine serum (FBS), $100 \mathrm{U} / \mathrm{ml}$ penicillin and
$100 \mu \mathrm{g} / \mathrm{ml}$ streptomycin sulfate, in a humidified atmosphere of $5 \% \mathrm{CO}_{2}$.

MTT assay. Cell viability was assessed by MTT assay, as described previously (16). A total of $5 \times 10^{4}$ cells $/ \mathrm{ml}$ were seeded in wells containing $100 \mu 1$ complete medium in a 96-well plate. After $24 \mathrm{~h}, \operatorname{Rg} 18$ or Rs11 was added at concentrations of 0 , $6.25,12.5,25,50,100$ and $200 \mu \mathrm{M}$ and cells were incubated for $48 \mathrm{~h}$. A total of $50 \mu \mathrm{l}$ MTT (stock solution, $5 \mathrm{mg} / \mathrm{ml}$ in PBS) was added, and the plates were incubated for an additional $4 \mathrm{~h}$. The medium was disposed and the formazan blue was dissolved using $100 \mu \mathrm{l} \mathrm{DMSO} /$ well. The optical density was measured at $540 \mathrm{~nm}$.

Cell cycle analysis. The cell cycle distribution was analyzed using propidium iodide staining as described previously (17). A total of $1 \times 10^{4}$ cells were collected from each experimental group, washed twice with PBS $\left(4^{\circ} \mathrm{C}\right)$, fixed and permeabilized with $70 \%$ ethanol at $4^{\circ} \mathrm{C}$ for $1 \mathrm{~h}$. The cells were washed once more with PBS and resuspended in a solution containing propidium iodide $(50 \mu \mathrm{g} / \mathrm{ml})$ and RNase A $(250 \mu \mathrm{g} / \mathrm{ml})$ for $30 \mathrm{~min}$ at room temperature. Fluorescence-activated cell sorting (FACS) was then performed to determine the cell cycle stage of each cell, using the Cytomics ${ }^{\mathrm{TM}}$ FC 500 flow cytometry and CXP cytometer software (version 2.0; (Beckman Coulter, Inc, Indianapolis, IN, USA).

Protein extraction and western blot analysis. Cells were collected by centrifugation at $200 \mathrm{x} \mathrm{g}$ for $10 \mathrm{~min}$ at $4^{\circ} \mathrm{C}$, washed twice with PBS at $4^{\circ} \mathrm{C}$, and centrifuged at $200 \mathrm{x} \mathrm{g}$ for $5 \mathrm{~min}$. The resulting cell pellet was resuspended in $1 \mathrm{X}$ protein lysis buffer (Intron Biotechnology, Inc., Seongnam, Korea). The protein concentration was determined using the Bio-Rad protein assay reagent (Bio-Rad Laboratories, Inc.) and bovine serum albumin as a standard solution according to the manufacturer's instruction. Equal amounts of cell lysates (5-15 $\mu \mathrm{l})$ were separated by 8-12\% SDS-PAGE and transferred into nitrocellulose membranes. The membranes were incubated with the aforementioned primary antibodies. The membranes were then incubated with a 1:2,000 dilution of horseradish peroxidase-conjugated Goat anti-mouse IgG (no. 31430), Goat anti-rabbit IgG (no. 31460), or Rabbit anti-Goat IgG (no. 81-1620) (Thermo Fisher Scientific Inc.) and visualized using an enhanced chemiluminescence detection system (Santa Cruz Biotechnology, Inc., Dallas, TX, USA), according to the manufacturer's protocol. $\beta$-actin was used as a loading control and densitometric analysis was performed using Quantity One ${ }^{\circledR}$ Software (version 4.6.3; Bio-Rad Laboratories, Inc.).

ROS detection (DCFH-DA assay). Intracellular ROS levels were detected using a DCFH-DA assay, as described previously (18). Cells $\left(5 \times 10^{4}\right.$ cells $\left./ \mathrm{ml}\right)$ were pretreated with and without $10 \mathrm{mM}$ $\mathrm{NAC}$ for $1 \mathrm{~h}$ and then treated with $150 \mu \mathrm{M} \operatorname{Rg} 18$ for $24 \mathrm{~h}$. The cells were collected and suspended in pre-warmed PBS $\left(37^{\circ} \mathrm{C}\right)$ prior to the addition of $20 \mu \mathrm{M}$ DCFH-DA and incubated for $30 \mathrm{~min}$ at $37^{\circ} \mathrm{C}$. When transported into the cells, DCFH-DA forms DCFH by deacetylation, and upon oxidation, fluorescent 2',7'-dichlorofluorescin is formed. Fluorescence intensity was analyzed by Cytomics $^{\mathrm{TM}} \mathrm{FC} 500$ flow cytometry and CXP cytometer software (version 2.0; Beckman Coulter, Inc., Indianapolis, IN, USA). 
A

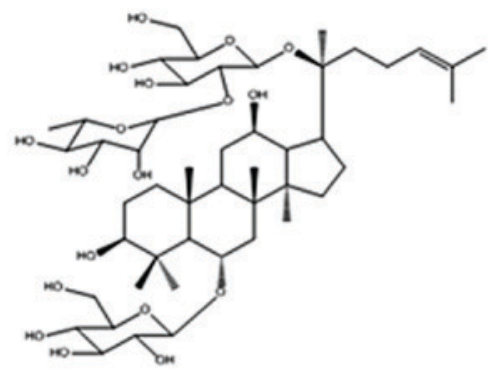

Ginsenoside Rg18

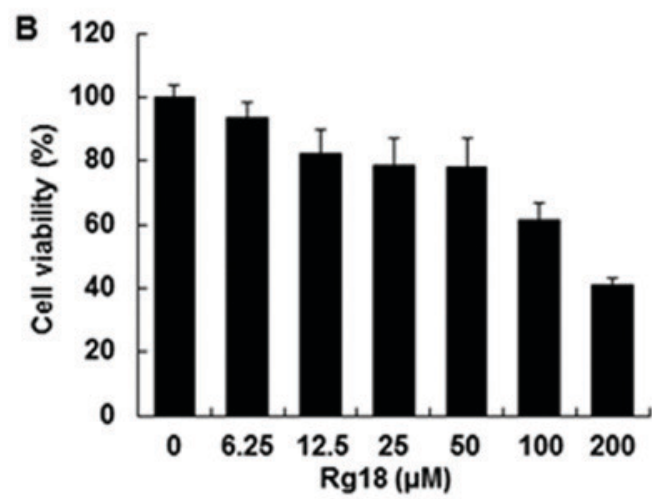

C

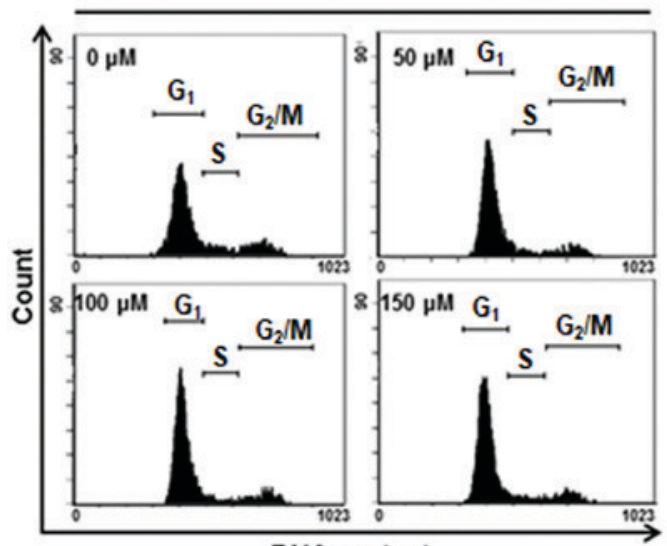

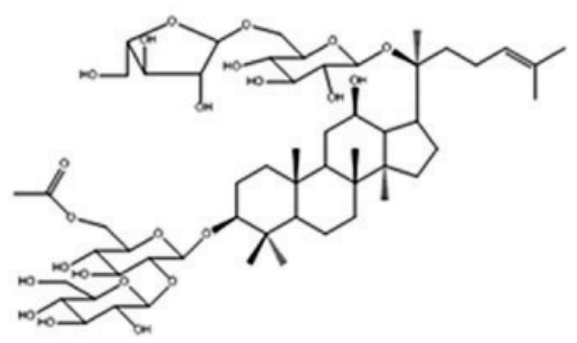

Ginsenoside Rs11
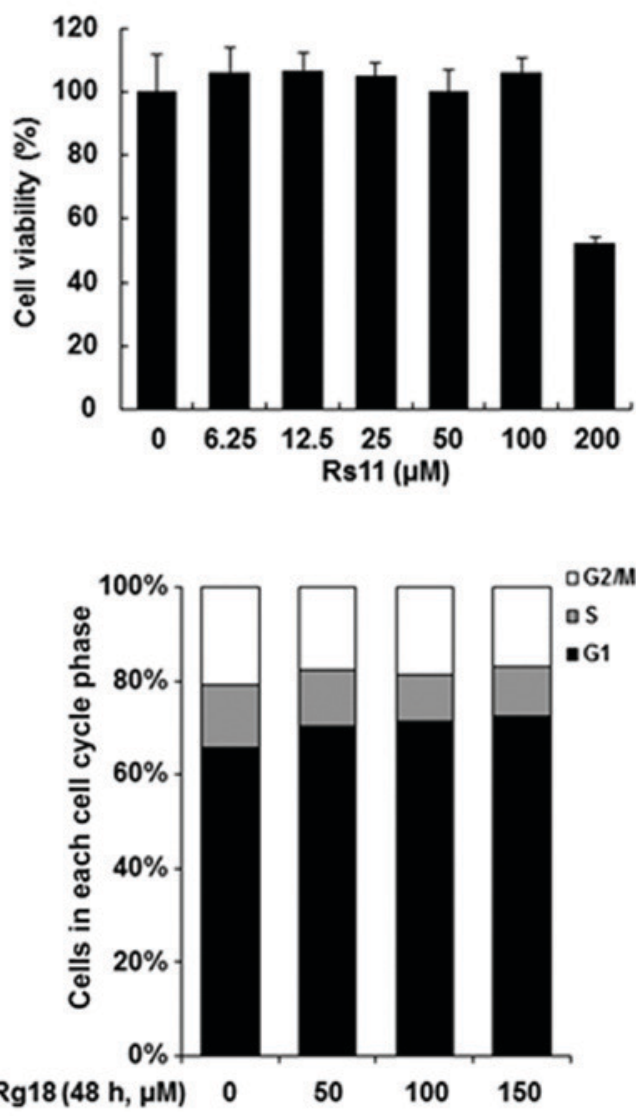

Figure 1. Effect of Rg18 on growth inhibition and cell cycle distribution in A549 cells. (A) The chemical structure of Rg18 and Rs11. (B) Cells were treated with the indicated concentrations of Rg18 and Rs11 for $48 \mathrm{~h}$ and cell viability was assessed using an MTT assay. (C) A549 cells were treated with Rg18 (50, 100 or $150 \mu \mathrm{M}$ ) for $48 \mathrm{~h}$ and flow cytometry analysis was performed to detect the percentage of cells in the different phases of the cell cycle. Data are presented as the mean \pm standard deviation of results from three independent experiments.

Statistical analysis. All data are presented as the mean \pm standard deviation of the results from three independent experiments. One-way analysis of variance followed by Dunnett's post hoc test was performed to identify differences between groups using GraphPad Prism software (version 5.01; GraphPad Software, Inc., La Jolla, CA, USA). $\mathrm{P}<0.05$ was considered to indicate a statistically significant difference.

\section{Results}

Rg18 inhibits cell proliferation and induces cell cycle arrest in A549 cells. The anti-proliferative effects of Rg18 and Rs11 were examined in A549 cells using an MTT assay (Fig. 1B) and half-maximal inhibitory concentration $\left(\mathrm{IC}_{50}\right)$ values. The A549 cells were treated with different concentrations of Rg18 and Rs11 for $48 \mathrm{~h}$, and it was found that Rg18 significantly decreases the viability of A549 cells, and these decreases are concentration-dependent $\left(\mathrm{IC}_{50}=140.09 \mu \mathrm{M}\right)$. However, Rs11 did not show obvious cytotoxic effects up to $100 \mu \mathrm{M}$ and it decreased cell viability at $200 \mu \mathrm{M}$ (cell viability: $51.78 \%$ ). The following experiments in A549 cells were conducted using $\operatorname{Rg} 18$ owing to their greater sensitivity to this ginsenoside. To investigate the mechanism of the anti-proliferative effect of Rg18, flow cytometry was used to identify changes in cell cycle distribution following treatment with Rg18. A549 cells were treated with various concentrations of $\operatorname{Rg} 18(0,50,100$ and $150 \mu \mathrm{M}$ ) for $48 \mathrm{~h}$, and the percentage of A549 cells in $\mathrm{G}_{1}$ phase increased from $63.3 \pm 1.5 \%$ (control group) to $68.6 \pm 2.1$, $69.8 \pm 1.4$ and $71.1 \pm 2.5 \%$ upon treatment with 50,100 and $150 \mu \mathrm{M}$ Rg18, respectively (Fig. 1C). 

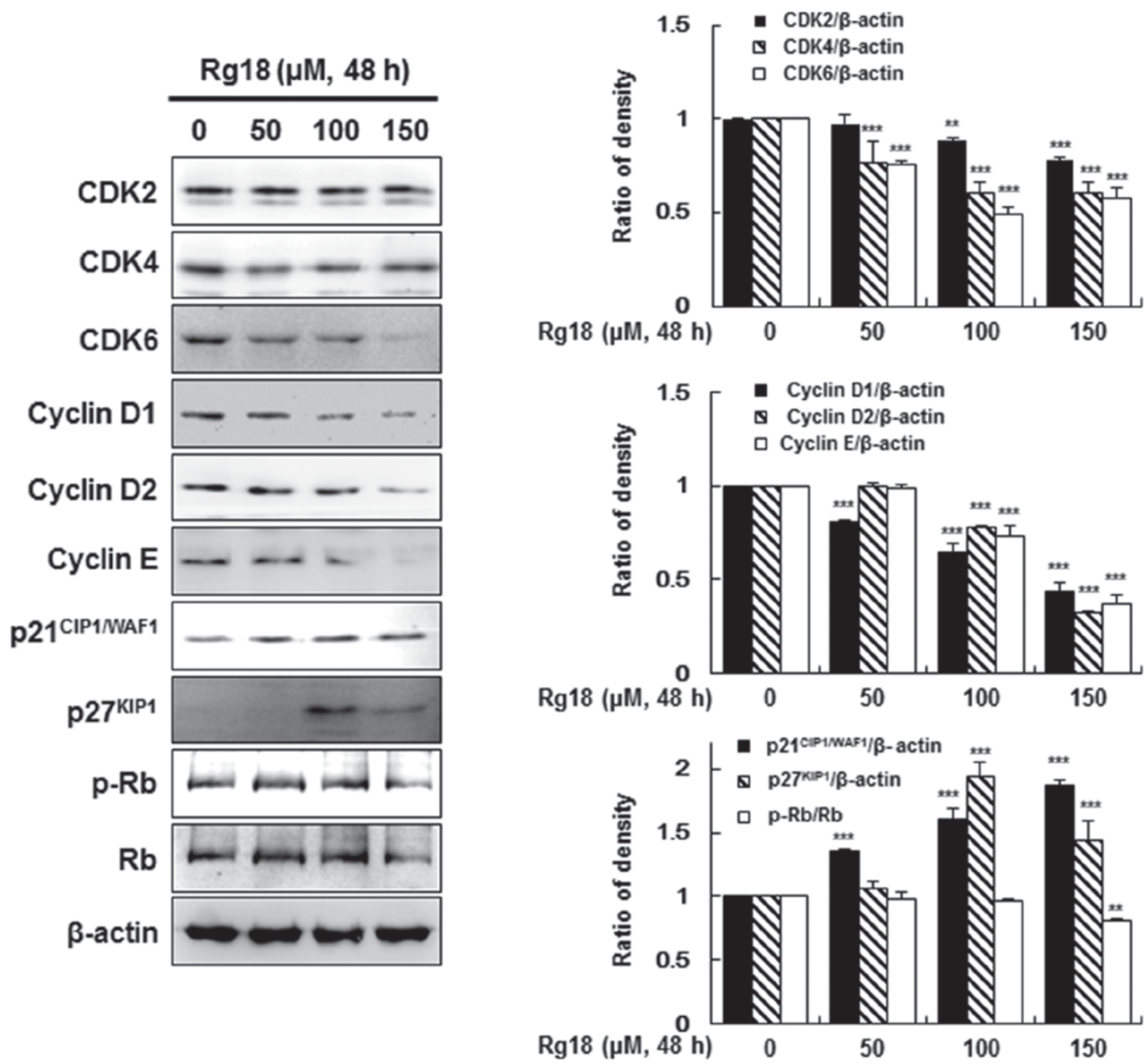

Figure 2. Effect of Rg18 on the expression of cell cycle-associated proteins. A549 cells were treated with $\operatorname{Rg} 18(50,100$ or $150 \mu \mathrm{M})$ for $48 \mathrm{~h}$. Total cell lysates were subjected to western blot analysis for $\mathrm{G}_{1}$ cell cycle regulatory proteins. The graphs represent the mean fluorescence intensity of the samples analyzed, relative to $\beta$-actin. ${ }^{* *} \mathrm{P}<0.01$ and ${ }^{* * *} \mathrm{P}<0.001$ vs. the control group. CDK2, cyclin dependent kinase $2 ; \mathrm{p} 21$, cyclin dependent kinase inhibitor $1 \mathrm{~A}$; $\mathrm{p} 27$, cyclin dependent kinase inhibitor $1 \mathrm{~B} ; \mathrm{p}-\mathrm{Rb}$, phosphorylated retinoblastoma protein.

Effect of Rg18 on protein expression levels of various $G_{I}$ phase cell cycle regulators in A549 cells. $\mathrm{Rg} 18$-induced $\mathrm{G}_{1}$ arrest in A549 cells (Fig. 1C), therefore, the protein expression levels of cell cycle regulatory molecules were investigated following 50, 100 or $150 \mu \mathrm{M} \operatorname{Rg} 18$ treatment. $\operatorname{Rg} 18$ treatment significantly reduced the protein expression level of CDK2, CDK4, CDK6, cyclin D1, cyclin D2 and cyclin E in A549 cells. Rg18 treatment also increased the protein expression levels of $\mathrm{p} 21^{\mathrm{CIP} 1 / \mathrm{WAF} 1}$ and $\mathrm{p} 27^{\mathrm{KIP} 1}$ after a 48 -h treatment. These proteins modulate CDK activity in various phases of the cell cycle, including $\mathrm{G}_{1}$. As Rb phosphorylation is influential in the transit from $G_{1}$ to $S$ phase (19), the phosphorylation levels of $R b$ were also examined. Following treatment with $150 \mu \mathrm{M} \operatorname{Rg} 18$ for $48 \mathrm{~h}$, the degree of phosphorylation and expression levels of $\mathrm{Rb}$ significantly decreased (Fig. 2).

Rg18 treatment results in upregulation of intracellular ROS levels and downregulates $\mathrm{p} 38, J N K$ and nuclear factor- $\kappa B$ $(N F-\kappa B)$ activation in A549 cells. ROS generation is an early sign of cell cycle arrest (20). To analyze ROS generation induced by $\mathrm{Rg} 18$ treatment, a DCFH-DA assay was performed. Following treatment with $150 \mu \mathrm{M} \mathrm{Rg} 18$ for $2 \mathrm{~h}$, the generation of ROS increased significantly, an effect that was blocked by pretreatment with the antioxidant NAC (Fig. 3A). To investigate the molecular mechanism of Rg18-induced $\mathrm{G}_{1}$ arrest, p38, ERK, JNK, and NF- $\mathrm{BB}$ (p65) phosphorylation were analyzed in $\mathrm{Rg} 18$-treated A549 cells. These molecules serve notable roles in cell cycle regulation $(21,22)$. $\operatorname{Rg} 18$ treatment resulted in a concentration-dependent decrease in $\mathrm{p} 38, \mathrm{JNK}$ and NF- $\mathrm{\kappa B} / \mathrm{p} 65$ phosphorylation, but there was no change to ERK phosphorylation levels (Fig. 3B).

\section{Discussion}

Previous studies have demonstrated that ginsenosides isolated from the root of $P$. ginseng $\mathrm{C}$. A. Meyer could inhibit cancer cell growth in vitro and in vivo via cell cycle arrest (14,23-25). 


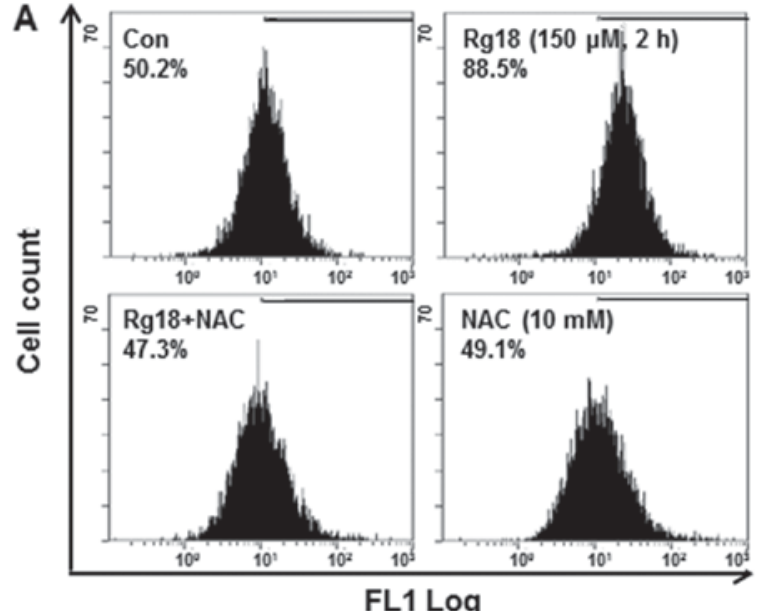

FL1 Log

B

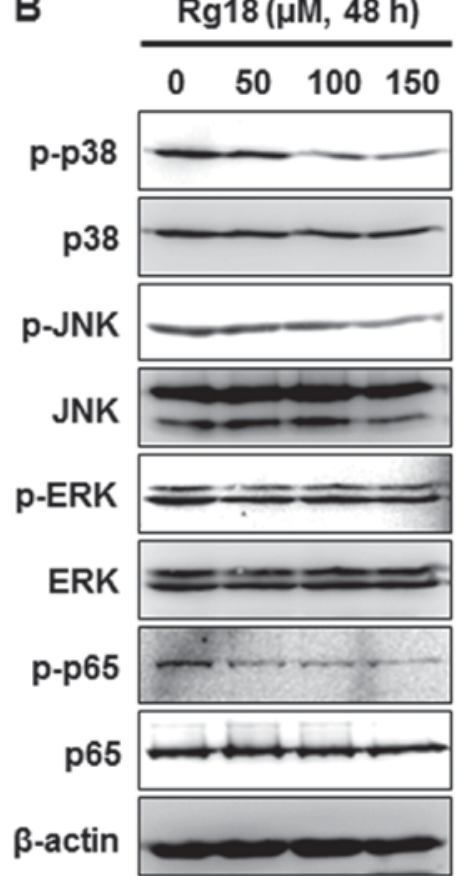

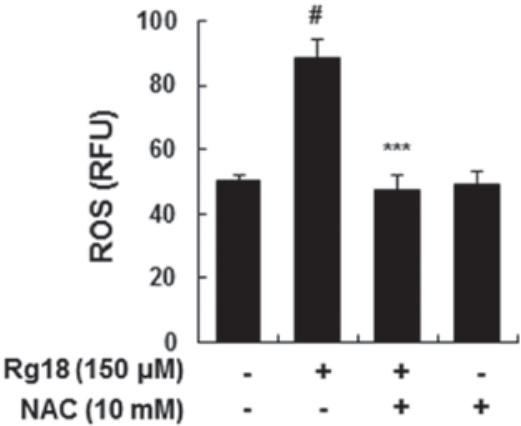

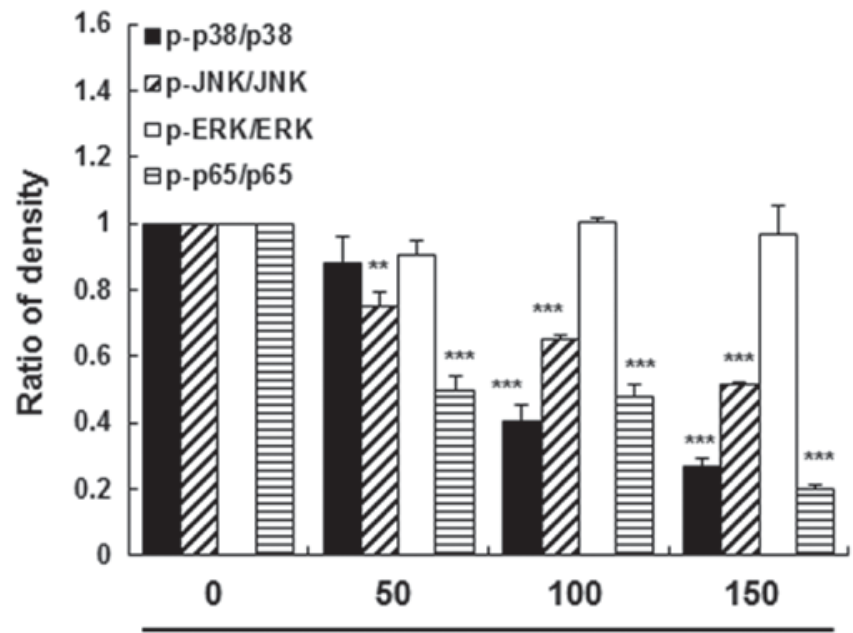

$\operatorname{Rg} 18(\mu \mathrm{M}, 48 \mathrm{~h})$

Figure 3. Rg18 upregulates the level of intracellular ROS and regulates the activation of p38, JNK and NF- $\mathrm{B}$ in A549 cells. (A) DCFH-DA was added to stain the A549 cells following treatment with $150 \mu \mathrm{M} \mathrm{Rg} 18$ for $2 \mathrm{~h}$. Flow cytometry was used to analyze the level of ROS in the cells. ${ }^{\sharp} \mathrm{P}<0.05$ vs. the control group; ${ }^{* * *} \mathrm{P}<0.001$ vs. Rg18 treatment group. (B) Western blot analysis was performed with antibodies against p-p38, p38, p-JNK, JNK, p-ERK, ERK, p-p65, p65 and $\beta$-actin. The histograms represent the mean fluorescence intensity of samples analyzed ${ }^{* *} \mathrm{P}<0.01$ and ${ }^{* * * *} \mathrm{P}<0.001$ vs. the control group. Data presented are the mean \pm standard deviation of the results from three independent experiments. ROS, reactive oxygen species; p-p38, phosphorylated p38 mitogen-activated

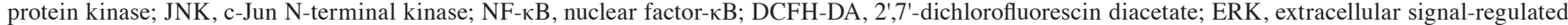
kinase; NAC, $N$-acetylcysteine.

In a previous study, it was demonstrated that four novel ginsenosides isolated from the $P$. ginseng root exhibited hydroxyl radical scavenging, anti-bacterial and cytotoxic activities (15). The aim of the present study was to determine whether Rg18 exerted an anti-proliferative effect on A549 cells and to characterize the molecular mechanism involved. The results demonstrated that $\operatorname{Rg} 18$ inhibited the proliferation of A549 cells and flow cytometric assays indicated that treatment with Rg18 lead to $G_{1}$ arrest in A549 cells.

Cell cycle progression is highly controlled by interactions of various regulators, including the cyclins and their catalytic partners, CDKs (6). CDK complexes are formed and activated at specific cell cycle phases; their activities are necessary for progression through distinct cell cycle phases (7). Progressing through the $\mathrm{G}_{1}$ phase requires either CDK4 or CDK6 activity, followed by the activation of CDK2. The cyclin-CDK complex formed during $G_{1}$ phase catalyzes the phosphorylation of the dominant inhibitors of $\mathrm{G}_{1} / \mathrm{S}$ phase cell cycle progression, the $\mathrm{Rb}$ family of tumor suppressor proteins, thereby allowing progression to $\mathrm{S}$ phase $(26,27)$. Cyclin-CDK complexes can bind $\mathrm{p} 21^{\mathrm{CIP} 1 / \mathrm{WAF} 1}$ and $\mathrm{p} 27^{\mathrm{KIP} 1}$, which inhibit kinase activities and prevent cell cycle progression (28). Western blot analysis demonstrated that Rg18 decreased the expression levels of cyclin D1, cyclin D2, cyclin E, CDK4, CDK6 and CDK2 in A549 cells. Furthermore, decreased CDK expression has been demonstrated to be associated with Rb under-phosphorylation, which is known to result in the sequestering of E2F, and thereby inhibition of the cell cycle progression (29). 
The results indicate that $\mathrm{Rg} 18$ influences cell cycle progression via the upregulation of $\mathrm{p} 21^{\mathrm{CIP} 1 / \mathrm{WAF} 1}$ and $\mathrm{p} 27^{\mathrm{KIP} 1}$ protein expression in A549 cells. It was apparent that strong CKI upregulation mediated Rg18-induced $\mathrm{G}_{1}$ phase arrest and the inhibition of cell growth. Overall, the $G_{1}$ phase blockade in A549 cells appeared to be mediated by the downregulation of CDK activity associated with CKI induction, such as by $\mathrm{p} 21^{\mathrm{CIP} 1 / \mathrm{WAF} 1}$ and $\mathrm{p} 27^{\mathrm{KIP} 1}$.

ROS are involved in multiple types of chemically induced cell cycle arrest; evidence indicates that increased oxidative stress is associated with cell cycle arrest induced by certain anticancer agents $(11,30)$. Among the protopanaxadiols, ginsenoside- $\mathrm{Rb}_{2}$ has been demonstrated to significantly increase the expression of genes encoding antioxidant enzymes, including superoxide dismutase and catalase in vitro (31). The present study demonstrated that Rg18 treatment increased intracellular ROS levels, which led to cell cycle arrest.

The mitogen-activated protein kinases (MAPKs) are also involved in cell cycle regulation (21), and three pathways, ERK, JNK and p38, are closely associated with the progression of a number of malignant types of cancer, including breast and ovarian cancer, and NSCLC $(32,33)$. JNK and p38 function in stress reactions and the induction of cell cycle arrest (34). The anticancer activity of 20(S)-protopanaxadiol in colon cancer cells is mediated by downregulation of the ERK, JNK and NF- $\mathrm{BB}$ signaling pathways (35). Additionally, compound $\mathrm{K}$ significantly inhibited phorbol 12-myristate 13-acetate-induced matrix metallopeptidase 9 protein expression and secretion via suppression of DNA-binding and activator protein-1 transcriptional activities, downstream of the p38, ERK and JNK pathways (36). However, it has been established that selenite-induced ROS arrest the cell cycle of NB 4 cells at the $\mathrm{G}_{1}$ phase by inhibiting the JNK/activating transcription factor 2 axis in vitro and in vivo (37). In the present study, it was demonstrated that Rg18 treatment suppressed the phosphorylation of JNK and p38 in A549 cells.

Data from previous studies indicated that blocking the activation of $\mathrm{NF}-\kappa \mathrm{B}$ could be a critical target for the regulation of cell proliferation and antioxidant behaviors (38-40). Ginsenoside $\mathrm{Rg} 3$ has been reported to inhibit NF- $\mathrm{B}$, induce $\mathrm{G}_{1}$ arrest and enhance susceptibility to docetaxel and other chemicals in prostate cancer cells (41). Furthermore, the ginsenoside $\mathrm{Rd}$ has been demonstrated to elevate intracellular glutathione levels by increasing $\gamma$-glutamyl cysteine ligase activation in rat hepatocyte H4IIE cells through NF- $\mathrm{BB}-\mathrm{DNA}$ binding (42). This result indicates that $N F-\kappa B$ serves as a cellular marker for cell cycle arrest in HL-60 cells. In the present study, Rg18 treatment inhibited the phosphorylation of $\mathrm{NF}-\kappa \mathrm{B} / \mathrm{p} 65$ in A549 cells. However, the exact mechanism of this effect, and whether it took place at the transcriptional and/or translational levels, requires further investigation.

In summary, $\operatorname{Rg} 18$ was found to inhibit the proliferation of A549 cells by arresting the cell cycle at the $\mathrm{G}_{1}$ phase by downregulating CDK2, CDK4 and CDK6 expression, in association with the induction of $\mathrm{p} 21^{\mathrm{CIP} 1 / \mathrm{WAF} 1}$ and $\mathrm{p} 27^{\mathrm{KIP} 1}$. The results indicated that this was, at least in part, due to intracellular ROS production and the downregulation of multiple signaling pathways, including JNK, p38 and $N F-\kappa B / p 65$. Further research is required to dissect the underlying mechanisms of these pathway changes. However, these results illustrate the potential use of $\operatorname{Rg} 18$ in cancer treatment, either alone or in combination with other anticancer agents.

\section{Acknowledgements}

Not applicable.

\section{Funding}

This study was supported by a research grant from the Korea Food Research Institute (E0145202).

\section{Availability of data and materials}

All data generated and/or analyzed during this study are included in this published article.

\section{Authors' contributions}

DGL and JSS designed experiments, analyzed the data and statistics, and drafted the manuscript. KTK, SYC, and MHL. did isolation, structural analysis, and a purity analysis of $\operatorname{Rg} 18$ and Rs11. KTL designed the study, coordinated the project and gave final approval of publication. All authors read and approved the final manuscript.

\section{Ethics approval and consent to participate}

Not applicable.

\section{Consent for publication}

Not applicable.

\section{Competing interests}

The authors declare that they have no competing interests.

\section{References}

1. Torre LA, Siegel RL and Jemal A: Lung cancer statistics. Adv Exp Med Biol 893: 1-19, 2016.

2. Molina JR, Yang P, Cassivi SD, Schild SE and Adjei AA: Non-small cell lung cancer: Epidemiology, risk factors, treatment, and survivorship. Mayo Clin Proc 83: 584-594, 2008.

3. Huang CY, Ju DT, Chang CF, Muralidhar Reddy P and Velmurugan BK: A review on the effects of current chemotherapy drugs and natural agents in treating non-small cell lung cancer. Biomedicine (Taipei) 7: 23, 2017.

4. Chen HS, Liu Y, Lin LQ, Zhao JL, Zhang CP, Jin JC, Wang L, Bai MH, Wang YC, Liu M and Shen BZ: Anti-proliferative effect of an extract of the root of Polygonum multiflorum Thunb. On MCF-7 human breast cancer cells and the possible mechanisms. Mol Med Rep 4: 1313-1319, 2011.

5. Dickson MA and Schwartz GK: Development of cell-cycle inhibitors for cancer therapy. Curr Oncol 16: 36-43, 2009.

6. Giacinti C and Giordano A: RB and cell cycle progression. Oncogene 25: 5220-5227, 2006.

7. Foster DA, Yellen P, Xu L and Saqcena M: Regulation of G1 cell cycle progression: Distinguishing the restriction point from a nutrient-sensing cell growth checkpoint(s). Genes Cancer 1: 1124-1131, 2010.

8. Nita M and Grzybowski A: The role of the reactive oxygen species and oxidative stress in the pathomechanism of the age-related ocular diseases and other pathologies of the anterior and posterior eye segments in adults. Oxid Med Cell Longev 2016: 3164734, 2016. 
9. Ray PD, Huang BW and Tsuji Y: Reactive oxygen species (ROS) homeostasis and redox regulation in cellular signaling. Cell Signal 24: 981-990, 2012

10. Wang Z, Zhao X and Gong X: Costunolide induces lung adenocarcinoma cell line A549 cells apoptosis through ROS (reactive oxygen species)-mediated endoplasmic reticulum stress. Cell Biol Int 40: 289-297, 2016.

11. Xiao W, Jiang Y, Men Q, Yuan L, Huang Z, Liu T, Li W and Liu X: Tetrandrine induces G1/S cell cycle arrest through the ROS/Akt pathway in EOMA cells and inhibits angiogenesis in vivo. Int J Oncol 46: 360-368, 2015.

12. Qi B, Zhang L, Zhang Z, Ouyang J and Huang H: Effects of ginsenosides-Rb1 on exercise-induced oxidative stress in forced swimming mice. Pharmacogn Mag 10: 458-463, 2014

13. Li J, Zhong W, Wang W, Hu S, Yuan J, Zhang B, Hu T and Song G: Ginsenoside metabolite compound K promotes recovery of dextran sulfate sodium-induced colitis and inhibits inflammatory responses by suppressing NF- $\kappa \mathrm{B}$ activation. PLoS One 9: e87810, 2014

14. Chung KS, Cho SH, Shin JS, Kim DH, Choi JH, Choi SY, Rhee YK, Hong HD and Lee KT: Ginsenoside Rh2 induces cell cycle arrest and differentiation in human leukemia cells by upregulating TGF- $\beta$ expression. Carcinogenesis 34: 331-340, 2013.

15. Lee DG, Lee AY, Kim KT, Cho EJ and Lee S: Novel dammarane-type triterpene saponins from Panax ginseng root. Chem Pharm Bull (Tokyo) 63: 927-934, 2015.

16. Plumb JA, Milroy R and Kaye SB: Effects of the $\mathrm{pH}$ dependence of 3-(4,5-dimethylthiazol-2-yl)-2,5-diphenyl-tetrazolium bromide-formazan absorption on chemosensitivity determined by a novel tetrazolium-based assay. Cancer Res 49: 4435-4440, 1989.

17. Choi JH and Lee KT: Costunolide-induced apoptosis in human leukemia cells: Involvement of c-jun N-terminal kinase activation. Biol Pharm Bull 32: 1803-1808, 2009.

18. Park EY, Kim JI, Leem DG, Shin JS, Kim KT, Choi SY, Lee MH, Choi JH, Lee YS and Lee KT: Resveratrol analogue (E)-8-acetoxy-2-[2-(3,4-diacetoxyphenyl)ethenyl]quinazoline induces apoptosis via Fas-mediated pathway in HL-60 human leukemia cells. Oncol Rep 36: 3577-3587, 2016.

19. Taya Y: RB kinases and RB-binding proteins: New points of view. Trends Biochem Sci 22: 14-17, 1997.

20. Verbon EH, Post JA and Boonstra J: The influence of reactive oxygen species on cell cycle progression in mammalian cells. Gene 511: 1-6, 2012

21. Zhang W and Liu HT: MAPK signal pathways in the regulation of cell proliferation in mammalian cells. Cell Res 12: 9-18, 2002

22. Joyce D, Albanese C, Steer J, Fu M, Bouzahzah B and Pestell RG: NF-kappaB and cell-cycle regulation: The cyclin connection. Cytokine Growth Factor Rev 12: 73-90, 2001.

23. Abe H, Arichi S, Hayashi T and Odashima S: Ultrastructural studies of Morris hepatoma cells reversely transformed by ginsenosides. Experientia 35: 1647-1649, 1979.

24. Kim HS, Lee EH, Ko SR, Choi KJ, Park JH and Im DS: Effects of ginsenosides $\mathrm{Rg} 3$ and $\mathrm{Rh} 2$ on the proliferation of prostate cancer cells. Arch Pharm Res 27: 429-435, 2004.

25. Cheng CC, Yang SM, Huang CY, Chen JC, Chang WM and Hsu SL: Molecular mechanisms of ginsenoside Rh2-mediated G1 growth arrest and apoptosis in human lung adenocarcinoma A549 cells. Cancer Chemother Pharmacol 55: 531-540, 2005

26. Hwang HC and Clurman BE: Cyclin E in normal and neoplastic cell cycles. Oncogene 24: 2776-2786, 2005.

27. Connell-Crowley L, Harper JW and Goodrich DW: Cyclin D1/Cdk4 regulates retinoblastoma protein-mediated cell cycle arrest by site-specific phosphorylation. Mol Biol Cell 8: 287-301, 1997.
28. Schmidt M, Lu Y, Parant JM, Lozano G, Bacher G, Beckers T and Fan Z: Differential roles of p21(Waf1) and p27(Kip1) in modulating chemosensitivity and their possible application in drug discovery studies. Mol Pharmacol 60: 900-906, 2001.

29. Lee KW, Kim HJ, Lee YS, Park HJ, Choi JW, Ha J and Lee KT: Acteoside inhibits human promyelocytic HL-60 leukemia cell proliferation via inducing cell cycle arrest at G0/G1 phase and differentiation into monocyte. Carcinogenesis 28: 1928-1936, 2007.

30. Wang R, Zhang Q, Peng X, Zhou C, Zhong Y, Chen X, Qiu Y, Jin M, Gong M and Kong D: Stellettin B induces G1 arrest, apoptosis and autophagy in human non-small cell lung cancer A549 cells via blocking PI3K/Akt/mTOR pathway. Sci Rep 6: 27071, 2016.

31. Chang MS, Lee SG and Rho HM: Transcriptional activation of $\mathrm{Cu} / \mathrm{Zn}$ superoxide dismutase and catalase genes by panaxadiol ginsenosides extracted from Panax ginseng. Phytother Res 13: 641-644, 1999

32. Dhillon AS, Hagan S, Rath O and Kolch W: MAP kinase signalling pathways in cancer. Oncogene 26: 3279-3290, 2007.

33. Roberts PJ and Der CJ: Targeting the Raf-MEK-ERK mitogen-activated protein kinase cascade for the treatment of cancer. Oncogene 26: 3291-3310, 2007.

34. Wagner EF and Nebreda AR: Signal integration by JNK and p38 MAPK pathways in cancer development. Nat Rev Cancer 9: 537-549, 2009.

35. Gao JL, Lv GY, He BC, Zhang BQ, Zhang H, Wang N, Wang CZ, Du W, Yuan CS and He TC: Ginseng saponin metabolite 20(S)-protopanaxadiol inhibits tumor growth by targeting multiple cancer signaling pathways. Oncol Rep 30: 292-298, 2013

36. Jung SH, Woo MS, Kim SY, Kim WK, Hyun JW, Kim EJ, Kim DH and Kim HS: Ginseng saponin metabolite suppresses phorbol ester-induced matrix metalloproteinase-9 expression through inhibition of activator protein-1 and mitogen-activated protein kinase signaling pathways in human astroglioma cells Int J Cancer 118: 490-497, 2006.

37. An JJ, Shi KJ, Wei W, Hua FY, Ci YL, Jiang Q, Li F, Wu P, Hui KY, Yang Y and Xu CM: The ROS/JNK/ATF2 pathway mediates selenite-induced leukemia NB4 cell cycle arrest and apoptosis in vitro and in vivo. Cell Death Dis 4: e973, 2013.

38. Kaltschmidt B, Kaltschmidt C, Hehner SP, Dröge W and Schmitz ML: Repression of NF-kappaB impairs HeLa cell proliferation by functional interference with cell cycle checkpoint regulators. Oncogene 18: 3213-3225, 1999.

39. Rajitha B, Belalcazar A, Nagaraju GP, Shaib WL, Snyder JP, Shoji M, Pattnaik S, Alam A and El-Rayes BF: Inhibition of NF- $\kappa$ B translocation by curcumin analogs induces G0/G1 arrest and downregulates thymidylate synthase in colorectal cancer. Cancer Lett 373: 227-233, 2016.

40. Tran KQ, Tin AS and Firestone GL: Artemisinin triggers a G1 cell cycle arrest of human Ishikawa endometrial cancer cells and inhibits cyclin-dependent kinase- 4 promoter activity and expression by disrupting nuclear factor- $\kappa \mathrm{B}$ transcriptional signaling. Anticancer Drugs 25: 270-281, 2014.

41. Kim SM, Lee SY, Cho JS, Son SM, Choi SS, Yun YP, Yoo HS Yoon DY, Oh KW, Han SB and Hong JT: Combination of ginsenoside Rg3 with docetaxel enhances the susceptibility of prostate cancer cells via inhibition of NF-kappaB. Eur J Pharmacol 631: $1-9,2010$

42. Kim ND, Pokharel YR and Kang KW: Ginsenoside Rd enhances glutathione levels in H4IIE cells via NF-kappaB-dependent gamma-glutamylcysteine ligase induction. Pharmazie 62: 933-936, 2007. 